\title{
TERAJU
}

Teraju: Jurnal Syariah dan Hukum

Volume 02 Nomor 02, September 2020

DOI: https://doi.org/10.35961/teraju.v2i02.157

\section{Transaksi Jual Beli Foreign Exchange Secara Online Perspektif Hukum Islam}

\author{
M. Azmi \\ STAIN Sultan Abdurrahman Kepulauan Riau \\ azmi@stainkepri.ac.id
}

\begin{abstract}
Abstrak
Artikel Perkembangan teknologi mutakhir tidak dapat dilepaskan dari pengaruhnaya terhadap kecendrungan gaya hidup dan perilaku ekonomi manusia, demikian juga dengan perilaku investasi. Forex online trading termasuk investasi finansial, khususnya pada investasi di bidang pasar uang dan bursa komoditi berjangka komoditi. Penulis berpandangan bahwa hukum transaksi forex online trading adalah haram karena tidak terpenuhinya rukun dan syarat jual beli dan mengandung unsur gharar, maisir (judi), riba dan melanggar ketentuan al-sharf yaitu adanya unsur spekulasi/untung-untungan, dan investasi ini tergolong dalam perdagangan berjangka (future market) artinya tempat/fasilitas memperjual belikan kontrak atas sejumlah komoditi atau instrumen keuangan dengan harga tertentu yang penyerahan barangnya disepakati akan dilakukan pada saat yang akan datang.
\end{abstract}

Kata Kunci: Hukum Islam, Forex Online Trading, Jual beli, Gharar

\begin{abstract}
This article The development of the latest technology cannot be separated from its influence on the lifestyle trends and human economic behavior, as well as investment behavior. Forex online trading includes financial investments, especially in investments in the field of money markets and commodity futures exchanges. The author is of the view that the online forex trading transaction law is haram because it does not fulfill the pillars and conditions of sale and purchase and contains elements of gharar, maisir (gambling), usury and violates the provisions of al-sharf that is the element of speculation / chance, and this investment is classified in trading futures (future market) means the place / facility of buying and selling contracts for a number of commodities or financial instruments at a certain price whose agreed delivery of goods will be carried out in the future.
\end{abstract}

Keywords: Islamic Law, Forex Online Trading, Buying and Selling, Gharar 


\section{Pendahuluan}

Pada mulanya dalam sistem perdagangan dunia orang melakukannya melalui sistem barter. Sistem barter merupakan sistem pertukaran antara barang dengan barang atau barang dengan jasa atau sebaliknya. Namun sistem ini menimbulkan banyak kendala.Oleh karenanya, untuk mengatasi kendala itu dipikirkanlah menggunakan alat tukar yang lebih efisien dan efektif.Alat tukar tersebut kemudian dikenal dengan uang.Belakangan, uang bukan lagi sekadar berfungsi sebagai alat tukar, namun juga memiliki fungsi- fungsi lainnya yang lebih luas ${ }^{1}$.

Jual beli sebagai sebuah perbuatan hukum yang mempunyai konsekuensi terjadinya peralihan hak atas sesuatu barang dari pihak penjual kepada pihak pembeli.Jual beli merupakan akad yang dibolehkan berdasarkan Alquran, sunnah dan ijma' para ulama. Dilihat dari aspek hukum, jual beli hukumnya mubah kecuali jual beli yang dilarang oleh syara'. Adapun dasar hukum dari Al Quran² Surah AlBaqarah:

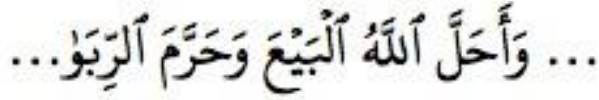

Artinya: Padahal Allah telah menghalalkan jual beli dan mengharamkan riba.(QS. $\mathrm{Al}$ Baqarah 2:275)

Perkembangan teknologi mutakhir tidak dapat dilepaskan dari pengaruhnaya terhadap kecendrungan gaya hidup dan perilaku ekonomi manusia, demikian juga dengan perilaku investasi. Perilaku investasi akhir- akhir ini cendrung bergeser dari investasi sektor riil ke arah

1 Nurul Huda, Mustafa Edwin Nasution, Investasi pada Pasar Modal Syariah, (Jakarta: Kencana Prenada Media Group, 2008), hal. 1.

${ }^{2}$ Abdul Ghofur Anshori, Perbankan Syariah di Indonesia, (Yogyakarta: Gadjah Mada Universiti Press, 2009), hal. 107. investasi finansial.Kehidupan finansial manusia dipengaruhi oleh perkembangan teknologi informasi yang berkembang saat ini $^{3}$.

Foreign online trading merupakan perdagangan yang dipengaruhi oleh perkembangan teknologi internet, dimana tidak melibatkan fisik dari perdagangan tersebut melainkan nilainya saja hanya nilainya saja sehingga transaksi dan instruksi- instruksi jual beli berada dalam satu platformsitus internet. ${ }^{4}$

Menurut Bank for International Settlement Triennial Bank Sentral Survey (BIS), pasar valuta asing atau forex adalah yang terbesar dan paling likuid di dunia perdaganagn rata-rata $\$ 5.1$ triliun per hari pada 2016. Forex online trading telah menjadi tren investasi masa kini yang banyak ditransaksikan oleh masyarakat dunia.Forex online trading termasuk dalam investasi perdagangan berjangka (future) $)^{5}$.

Prinsip dasarnya, sama seperti semua jenis perdagangan yaitu membeli saat harga rendah dan jual kembali setelah harganya naik. Ini berlaku untuk emas, realestate, tanah, anthurium, sampai beras.Untuk forex, karena diperdagangkan dalam bentuk pasangan (misalnya EUR/USD, GBP/USD, USD/JPY, dsb. $)^{6}$ maka transaksi bisa dilakukan dalam dua arah yaitu para trader membeli suatu pasang mata-uang pada saat nilainya rendah dan menjualnya kembali pada saat

\footnotetext{
${ }^{3}$ Hasbiyallah, Sudab Syariabkah Muamalahmu?,(Yogyakarta: Salma Idea, 2014), hal. 11

${ }^{4}$ Sawidja Widoatmodji. Lie Ricky Ferlianto, dkk, Forex Online Trading tren Investasi Masa Kini (Jakarta: Kompas Gramedia, 2012), hal. 69.

${ }^{5}$ Hiqmad Muharman Pilliangsani, Cara Mudah Memulai Bisnis Forex di Internet dengan US\$ 1, (Jakarta: PT Elex Media Komputindo, 2010), hal. 1

${ }^{6}$ Triton Prawira budi, Revolusi investasi di Era Cyber dengan Forex On-Line Trading, (Yogyakarta: Cemerlang Publishing, 2008), hal. 18.
} 
nilainya tinggi, atau sebaliknya menjual suatu pasang mata uang saat bernilai tinggi dan membelinya kembali mata uang tersebut saat nilainya turun. Mata uang ini diperdagangkan melalui dealer/broker, yang menjadi perantara antara trader dengan bank/marketmaker.

Forex online trading telah menjadi tren investasi masa kini yang banyak ditransaksikan oleh masyarakat dunia.Forex online trading termasuk dalam investasi perdagangan berjangka (future).Salah satu kelebihan dalam berivestasi pada perdagangan berjangka khususnya forexdengan adanya pengawas dari pemerintah.Undang-Undang Nomor 10 Tahun 2011 tentang Perubahan Atas Undang-Undang Nomor 32 Tahun 1997 Tentang Perdagangan Berjangka Komoditi.Pemerintah Indonesia menetepakan bahwa badan pengawas perdagangan berjangka merupakan unit kerja yang berada di bawah, dan bertanggung jawab kepada mentri perdagangan, yang bernama Badan Pengawas Perdagangan Berjangka Komoditi (Bappepti).Saat ini ada 61 perusahaan atau broker forex resmi yang telah terdaftar di Bappepti.dan bisa juga menggunakan beroker forex legal yang berasal dari luar negeri. ${ }^{7}$

\section{Pembahasan}

\section{A. Hukum Islam}

Hukum Islam adalah seperangkat peraturan berdasarkn wahyu Allah dan sunnah Rasul tentang tingkah laku manusia mukalaf yang diakui dan diyakini berlaku mengikat untuk semua umat yang beragama Islam, untuk mewujudkan kedamaian

${ }^{7}$ Ginia Habiba, Analisis Teknikal Dalam Menentukan Open dan Close Position pada Investasi Forex Online Pasangan Mata Uang EUR/USD periode 2010-2011, (Bogor: Fakultas Ekonomi dan Manajemen, 2014). dan kepatuhan baik secara vertikal maupun horizontal ${ }^{8}$.

Secara garis besar ulama membagi hukum kepada dua macam yaitu, hukum taklifi dan hukum wadhi:

1. Hukum Taklifi

Hukum Taklifi ialah apa yang mengandung kehendak meminta terhadap mukallaf untuk memperbuatnya atau menahannya dari memperbuat, atau memilih antara melakukan dan tidak melakukan. Jadi hukum taklifi adalah hukum yang dibebankan kepada mukallaf yang mengandung tiga unsur pokok, yaitu tuntutan untuk melakukan, atau larangan (untuk tidak melakukan) atau kebolehan memilih (antara melakukan atau tidak melakukan).

Setelah para imam mujtahid atau para ahli ushul figh meneliti dari khitab syar'i yang berhubungan dengan perbuatan mukallaf yang secara pokok berisi tiga unsur tersebut, maka jumhur ulama ushul membagi hukum taklifi itu kepada 5 (lima) macam, yaitu: ${ }^{9}$

a. Ijab (Mewajibkan)

Wajib menurut syara' adalah sesuatu yang dituntut oleh syara' untuk memperbuatnya dari mukallaf dengan tuntutan yang pasti atau mesti. Misalnya, ayat Artinya: Hai orang-orang yang beriman, pelibaralah dirimu dan keluargamu dari api neraka (QS AtTahrim [66]: 6)

b. Mandub (Sunnat)

Kata mandub dari segi bahasa berarti sesuatu yang dianjurkan. Adapun menurut

8Rohidin, Pengantar Hukum Islam, (Yogyakarta: Lintang Rasi Aksara Books, 2016), hal. 2.

${ }^{9}$ Abdul Hayat, Ushul Fiqh Dasar-dasar untuk memahami Figh Islam, (Jakarta: Rajawali Pers, 2016), hal. 13. 
istilah, seperti dikemukakan Abdul Karim Zaidan, adalah suatu perbuatan yang dianjurkan oleh Allah dan Rasul-Nya, di mana akan diberi pahala orang yang melaksanakannya, namun tidak dicela orang yang tidak melaksanakannya. Mandub disebut juga sunah, nafilah, mustahab, tathawnu', ihsan, dan fadilah. Istilah-lstilah tersebut menunjukkan pengertian yang sama

c. Tahrim (Haram)

Kata haram secara etimologi berarti sesuatu yang dilarang mengerjakannya.Secara terminologi ushul fiqh, kata haram berarti sesuatu yang dilarang oleh Allah dan RasulNya, di mana orang yang melanggarnya dianggap durhaka dan diancam dengan dosa, dan orang yang meninggalkannya karena menaati Allahdiberi pahala.Misalnya, larangan berzina dalam firman Allah.dan janganlah kamu mendekati zina; sesunggubnya zina itu adalah suatu perbuatan yang keji dan suatu jalan yang buruk. (QS. al-Israa' [17]: 32).

d. Ibahah (Mubah)

Menurut istilah ushul fiqh.Mubah ialah apa-apa yang dibolehkan oleh syara' terhadap mukallaf untuk memilih antara mengerjakan atau meninggalkannya.Syara' tidak menuntut mukallaf untuk melakukan perbuatan itu dan tidak untuk mencegahnya.

e. Karahah (Makruh)

Secara bahasa kata makruh berarti sesuatu yang dibenci. Dalam istilah ushul figh, kata makruh menurut mayoritas ulama ushul fiqh berarti sesuatu yang dianjurkan syariat untuk meninggalkannya, di mana bilamana ditinggalkan akan mendapat pujian dan apabila dilanggar tidak berdosa. Misalnya, seperti dikemukakan Wahbah az-Zuhaili, dalam mazhab Hambali ditegaskan makruh hukumnya berkumur dan memasukkan air ke hidung secara berlebihan ketika akan berwudhu di siang hari Ramadhan, karena dikhawatirkan air akan masuk ke rongga kerongkongan dan tertelan.

2. Hukum Wadh'i

Hukum Wadh'i ialah khitab syari' yang berhubungan dengan perbuatan orang mukallaf yang terkadang mengandung tuntutan atau pilihan (yaitu yang dibicarakan pada hukum taklifi), di mana adakalanya suatu peristiwa terhadap sesuatu yang lain adalah sebagai sebab, sebagai syarat atau sebagai penghalang. ${ }^{10}$ Pembagian Hukum Wadh'i, yaitu:

a. Sebab

Sebab menurut bahasa berarti sesuatu yang bisa menyam paikan seseorang kepada sesuatu yang lain ${ }^{11}$. Menurut istilah ushul fiqh, seperti dikemukakan Abdul Karim Zaidan, sebab berarti: Yaitu sesuatu yang dijadikan oleh syariat sebagai tanda bagi adanya hukum, dan tidak adanya sebab sebagai tanda bagi tidak adanya hukum. Misalnya, tindakan perzinaan menjadi sebab (alasan) bagi wajib dilaksanakan hukuman atas pelakunya, keadaan gila menjadi sebab (alasan) bagi keharusan ada pembimbingnya, dan tindakan perampokan

${ }^{10}$ Abdul Hayat, Ushul Figh Dasar-dasar untuk memahami Figh Islam..., hal. 36

${ }^{11}$ Satria Effendi, M. Zein, Ushul Fiqh, (Jakarta: Kencana, 2017), hal. 49 
sebagai sebab bagi kewajiban mengembalikan benda yang dirampok kepada perniliknya.

Sebab terbagi kepada dua macam, yaitu:

1) Sebab yang di luar kemampuan jangkauan mukallaf. Misalnya:

Tergelincirnya matahari sebagai sebab wajibnya melaksanakan shalat zhuhur dan ashar, gelapnya malam sebagai sebab wajibnya melaksanakan shalat maghrib dan isya, terbitnya fajar sebagai sebab wajibnya melaksanakan shalat subuh. Firman Allah SWT. Artinya: Dirikanlah shalat dari sesudah matahari tergelincir sampai gelap malam dan (dirikanlah pula shalat) subuh. Sesunggubnya shalat subub itu disaksikan (oleh malaikat) (QS Al-Isra [17]: 78).

2) Sebab yang merupakan perbuatan mukalaf dan dalam batas kemampuannya. Misalnya:

Perjalanan menjadi sebab bagi bolehnya berbuka puasa di siang hari Ramadhan, pernbunuhan disengaja menjadi sebab bagi dikenakan hukuman qisas atas pelakunya, dan akad transaksi jual beli menjadi sebab bagi perpindahan milik dari pihak penjual kepada pihak pembeli.

b. Syarat

Menurut istilah ushul fiqh, seperti dikemukakan Abdul Karim Zaidan, syarat adalah: Sesuatu yang tergantung kepadanya ada sesuatu yang lain, dan berada di luar dari hakikat sesuatu itu. Misalnya, wudhu adalah sebagai syarat bagi sahnya shalat dalam arti adanya shalat tergantung kepada adanya wudhu, namun pelaksanaan wudhu itu sendiri bukan merupakan bagian dari pelaksanaan shalat.

Para ulama ushulfigh membagi syarat kepada dua macam: ${ }^{12}$

1) Syarat syar'i, yaitu syarat yang datang langsung dari syariat sendiri. Misalnya, keadaan rusyd (kemampuan untuk mengatur pembelanjaan sehingga tidak menjadi mubazir) bagi seorang anak yatim dijadikkan oleh syariat sebagai syarat bagi wajib menyerahkan harta miliknya kepadanya.

2) Syarat ja'ly, yaitu syarat yang datang dari kemauan orang mukalaf itu sendiri. Misalnya, seorang suami berkata kepada istrinya: Jika engkau memasuki rumah si Fulan, maka jatuhlah talakmu satu," dan seperti pernyataan seseorang bahwa ia baru bersedia menjamin untuk membayarkan utang si Fulan dengan syarat si Fulan itu tidak mampu membayar utangnya itu.

c. Mani'

Kata mani secara etimologi berarti penghalang dari sesuatu. Secara terminologi, seperti dikemukakan oleh Abdul Karim Zaidan, kata mani' berarti: Sesuatu yang ditetapkan syariat sebagai pengahalang bagi adanya hukum atau penghalang bagi berfungsinya suatu sebab. Misalnya, seorang wanita yang mengalami haid, maka tidak ada kewajiban shalat terhadapnya.

${ }^{12}$ Abdul Hayat, Ushul Fiqh Dasar-dasar untuk memahami Figh Islam..., hal. 60 
Haid adalah mani' (penghalang) wajibnya shalat. ${ }^{13}$

\section{B. Jual Beli Dalam Islam}

Jual beli Adalah proses pemindahan hak milik, barang atau harta kepada pihak lain dengan menggunakan uang sebagai alat tukarnya. Menurut etimologi, jual beli adalah pertukaran sesuatu dengan sesuatu (yang lain). Kata lain dari jual beli dalam bahasa arab adalah alba'i,asy-syira', al-mubadah, dan attijarah yang secara bahasa adalah tukar menukar. Sedangkan menurut istilah adalah tukar menukar atau peralihan kepemilikan dengan cara pergantian menurut bentuk yang diperbolehkan oleh syara' atau menukarkan barang dengan barang atau barang dengan uang, dengan jalan melepaskan hak milik dari seseorang terhadap orang lainnya atas kerelaan kedua belah pihak.

Jual beli merupakan akad yang dibolehkan berdasarkan Alquran, sunnah dan ijma' para ulama. Dilihat dari aspek hukum, jual beli hukumnya mubah kecuali jual beli yang dilarang oleh syara', Adapun dasar hukum dari $\mathrm{Al}$ Quran antara lain:

Surah Al-Baqarah (2) ayat 275:

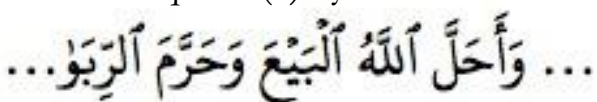

Artinya: Padahal Allah telah menghalalkan jual beli dan mengharamkan riba.(QS. Al Baqarah 2:275)

Surah An-Nisa' (4) ayat 29:

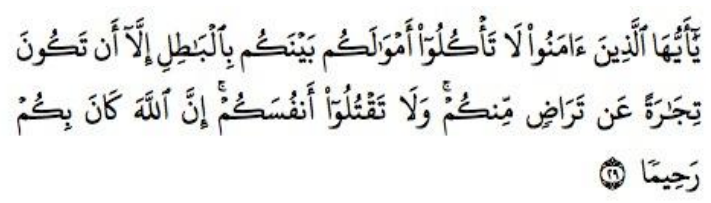

Artinya: Hai orang-orang yang beriman, janganlah kamu saling memakan harta sesamamu dengan jalan yang batil. kecuali hal.41

${ }^{13}$ Satria Effendi, M. Zein, Ushul Fiqh..., dengan jalan perniagaan yang berlaku dengan Suka sama.uka di antara kamu. Dan janganlah kamu membunuh dirimu; Sesunggubnya Allab adalab Maba Penyayang kepadamu.

Hadits

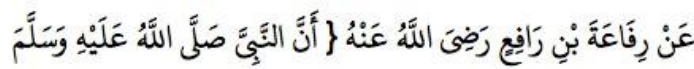

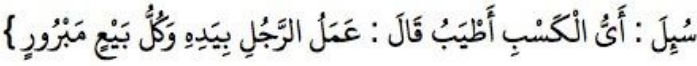

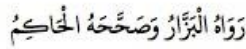

Artinya: Dari Rifa'ab ibnu Raft' babwa Nabi ditanya usaba apakah yang paling baike? Nabi menjawab: Usaba seseorang dengan tangannya sendiri dan setiap beli yang mabrur.(Diriwayatkan oleh Al-Bazzar dan dishahihkan oleh Al-Hakim).

C. Pandangan Hukum Islam Tentang Jual Beli Mata Uang (Al-Sharf)

1. Pandangan Mazhab Tentang Jual Beli mata Uang

Jual beli ini terdapat dua syarat khusus; pertama, tidak ada penundaan (yaitu harus segera) dan kedua, tidak ada penambahan (yaitu disyaratkan agar sebanding) ${ }^{14}$. Masalah ketiga: Masa penukaran uang yang dilakukan dengan tunai Para ulama sepakat bahwa termasuk syarat penukaran uang yaitu agar dilakukan dengan tunai. Mereka berbeda pendapat tentang waktu yang membatasi pengertian ini:

a. Abu Hanifah dan Syafi'i mengatakan bahwa pertukaran uang bisa dilakukan dengan tunai selama dua orang yang saling menukar uang belum berpisah baik penerimaan itu disegerakan atau ditunda.

b. Imam Malik mengatakan bahwa jika penerimaan tersebut di majlis tersebut ditunda, maka penukaran itu dibatalkan,

${ }^{14}$ Abdul Ghofur Anshori, Perbankan Syariah di Indonesia, (Yogyakarta: Gajah Mada Universiaty Press, 2009) hal. 172-173. 
meskipun keduanya belum berpisah, sehingga dia membenci untuk saling mengadakan janji di masjlis tersebut. Sebab perbedaan pendapat: Kebimbangan mereka tentang pengertian sabda Nabi SAW, kecuali dengan tunai. Karena hal ini berbeda mengenai sedikit dan banyaknya.

Ulama yang berpendapat bahwa lafazh ini sesuai bagi orang yang belum berpisah dari majlis (maksudnya, dikatakan bahwa dia menjual dengan tunai) mereka mengatakan dibolehkan menunda di majlis. ${ }^{15}$ Dan ulama yang berpendapat bahwa lafazh tersebut tidak sesuai kecuali jika terjadi penerimaan dari dua orang yang saling menukar uang dengan segera, mereka mengatakan jika penerimaan tersebut ditunda dari akad di majlis, maka penukaran tersebut batal, berdasarkan kesepakatan mereka bahwa pengertian ini menurut mereka tidak dibolehkan adanya hiwalah (pemindahan), hamalah (tanggungan) dan juga khiyar pada penukaran uang. Kecuali pendapat yang diriwayatkan dari Abu Tsaur bahwa dia membolehkan khiyar dalam hal ini.

2. Fatwa DSN tentang Jual beli Mata Uang (al-sharf)

Ketentuan dari Majelis Ulama Indonesia, sehubungan dengan perdagangan valuta asing. Ketentuan umum tentang seputar kegiatan transaksi jual-beli valuta asing berdasarkan Fatwa Dewan Syariah Nasional Nomor: 28/DSNMUI/III/2002 tentang Sharf pada

${ }^{15}$ Ibnu Rusyd, Bidayatul Mujtabid (Jakarta: Pustaka Azzam), hal. 388-389. prinsipnya boleh dengan ketentuan sebagai berikut ${ }^{16}$ :

a. Tidak untuk spekulasi (untunguntungan)

b. Ada kebutuhan transaksi atau untuk berjaga-jaga (simpanan)

c. Apabila transaksi dilakukan terhadap mata uang sejenis maka nilainya harus sama dan secara tunai (at-taqabudh).

d. Apabila berlainan jenis maka harus dilakukan dengan nilai tukar (kurs) yang berlaku pada saat transaksi dilakukan dan secara tunai.

Adapun ketentuan mengenai hukum Jenis-jenis Transaksi Valuta Asing, dijelaskan dalam fatwa tersebut sebagai berikut:

a. Transaksi Spot, yaitu transaksi pembelian dan pen-jualan valuta asing (valas) untuk penyerahan pada saat itu (over the counter) atau penyelesaiannya paling lambat dalam jangka waktu dua hari. Hukumnya adalah boleh, karena dianggap tunai, sedangkan waktu dua hari dianggap sebagai proses penyelesaian yang tidak bisa dihindari dan merupakan transaksi internasional.

b. Transaksi Forward, yaitu transaksi pembelian dan penjualan valas yang nilainya ditetapkan pada saat sekarang dan diberlakukanuntuk waktu yang akan datang, antara $2 \times 24$ jam sampai dengan satu tahun. Hukumnya adalah haram, karena harga yang digunakan adalah harga yang diperjanjikan (muwa'adah) dan penyerahannya dilakukan di kemudian hari, padahal harga pada waktu

${ }^{16} \mathrm{M}$. Ichwan Sam, Hasanudding, dkk, Himpunan Fatwa Kenangan Syariah Dewan Syariab Nasional MUI, (Jakarta: Erlangga, 2014) hal. 161162. 
penyerahan tersebut belum tentu sama dengan nilai yang disepakati, kecuali dilakukan dalam bentuk forward agreement untuk kebutuhan yang tidak dapat dihindari (lil hajab).

c. Transaksi Swap, yaitu suatu kontrak pembelian atau penjualan valas dengan harga spot yang dikombinasi-kan dengan pembelian antara penjualan valas yang sama dengan harga forward. Hukumnya haram, karena mengandung unsur maysir (spekulasi).

d. Transaksi Option, yaitu kontrak untuk memperoleh hak dalam rangka membeli atau hak untuk menjual yang tidak harus dilakukan atas sejumlah unit valuta asing pada harga dan jangka waktu atau tanggal akhir tertentu. Hukumnya haram, karena mengandung unsur maisir (spekulasi).

D. Mekanisme Proses dalam Transaksi Forex Online Trading

Bisnis forex adalah kegiatan mengelola modal sendiri dengan cara melakukan transaksi jual beli mata uang di pasar forex secara online untuk dapat keuntungan/profit. Di pasar forex itu ada barang yang namanya EUR/USD, GBP/USD, GBP/JPY dan lain-lain.Setiap barang ini ada harganya, ada pula grafik pergerakan harganya, yang dilakukan adalah jual beli barang tersebut. Misalnya: harga barang sekian, kemudian trader beli, setelah itu harganya naik, lalu trader Close (menutup penjalan) maka hasilnya untung. Tapi jika Beli kemudian harganya turun, lalu trader Close tentu saja hasilnya rugi. ${ }^{17}$

${ }^{17}$ Isma'il, Jutaan Dolar Dari Bisnis Forex (Yogyakarta: Shafa Media, 2013), hal. 13.
Dalam mekanisme ini dalam bertransaksi di forex online trading menggunakan platfrom internet dan Metatrader adalah software yang cukup mudah untuk melakukan transaksi si pasar forex. Penggunaan software Metatradersangat lah mudah, sama seperti penggunaan windows pada umumnya, yaitu mengendalikannyadengan mousendan klik kiri/klik kanan. klik kiri untuk ekskusi, klik kanan untuk menampilkan menunya. ${ }^{18} \quad$ Dan untuk Order (transaksi) maka bisa menekan F9 atau klik kanan pada layar Market Wach (tabel mata uang) lalu pililh menu New Order.127 Metatrader adalah salah satu aplikasi yang digunakan oleh trader untuk mengakses ke sistem broker forex secara online. Dengan Metatrader, trader bisa melakukan trading forex secara mudah hampir semua broker di dunia men-support trader mereka dengan platform aplikasi perdagangan Metatrader ini.

Alur Transaksi Forex Online Trading

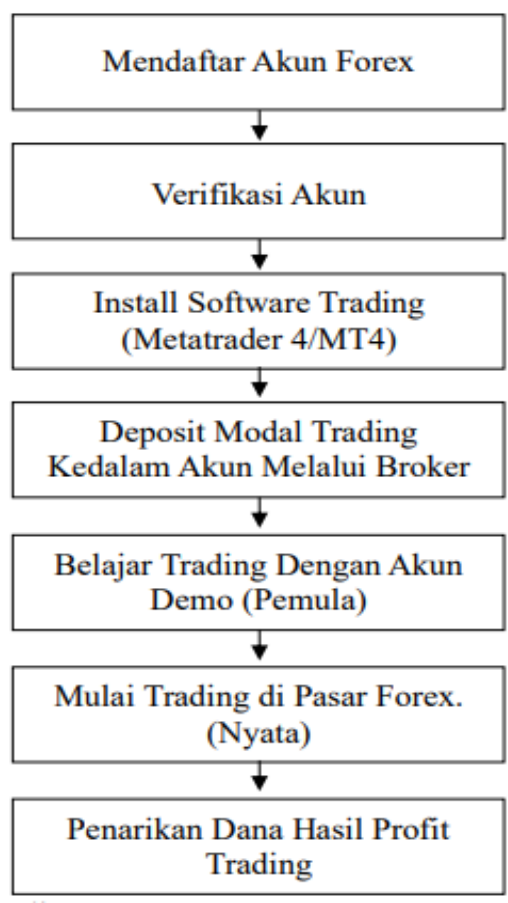

${ }^{18}$ Boy Loen, Sonny Ericson, dkk. Manajemen aktiva pasiva Bank Devisa, Jakarta: Grasindo, 2008), hal. 27-30. 
E. Perspektif Hukum Islam Terhadap Transaksi Forex Online Trading

Pada dasarnya perdagangan forexsama halnya dengan jual beli pada umumnya. Jika di dalam perdagangan biasa terdapat pembeli dan penjual, perdagangan forex pun sama membutuhkan adanya pembeli dan juga penjual. Perbedaanya hanya terletak pada pertemuan yang terjadi diantara penjual dan juga pembeli.Didalam perdagangan forex, pihak pembeli dan juga penjual tidak pernah melakukan pertemuan fisik secara langsung dan juga tidak pernah terjadi penyerahan secara fisik juga.Semua aktivitas tersebut diperantarai oleh lembaga arbitrase yang sering kali Anda kenal dengan sebutan Pialang atau Broker.

Transaksi (jual beli) yang menunjukkan suatu hal yang tidak pasti tidak jelas dalam fiqih islam dimasukkan dalam bentuk transaksi gharar. Jual beli gharar tersebut dilarang dalam Islam, sedangkan model analisis dalam forex trading menunjukkan adanya transaksi jual beli yang mengandung unsur gharar.Bahkan bisa masuk pada maysir (perjudian), karena kedua belah pihak tidak mengetahui hasil akhirnya (untung ruginya).Berdasarkan pada hal tersebut, maka dapat dipahami bahwa sebenarnya dalam forex trading ini ialah untuk mengejar keuntungan yang cepat.Karena jika seorang memang membutuhkan satu mata uang, jauh lebih praktis menggunakan jasa money charger konvensional.

Transaksi forex trading perdagangan dilakukan melalui platform internet dan pembayarannya melalui rekening.Eksekusi pembayarannya terjadi saat trader melakukan penutupan transaksi (close position). Pada saat trader melakukan pembelian atau penjualan pada open position uang dalam rekeningnya tidak berubah sama sekali, uang dalam rekening hanya akan ada perubahan saat dilakukannya penutupan transaksi. Dalam trading forex juga ada sistem margin dan leverage. Sistem margin dan leverage itu memungkinkan broker forex untuk meminjamkan dana secara proporsional dengan jaminan dana yang diberikan oleh trader. Pada umumnya leverage yang ditawarkan 1:100 atau 1:200. Ini artinya dengan satu bagian yang dikeluarkan, trader dapat membeli atau menjual sebanyak 100 bagian.Inilah kelebihan margin trading di mana yang dibutuhkan hanyalah jaminan saja untuk menjual atau membeli barang yang dibutuhkan.Sistem transaksi tersebut merupakan kegiatan penjualan suatu barang yang tidak dimiliki oleh penjual, tidak ada hak kepemilikan yang nyata melainkan yang yang dipinjamkan broker yang diolah untuk diperjual belikan dengan harapan untuk mendapatkan keuntungan lebih dari transaksi trsebut. ${ }^{19}$

Pada prinsip syariahnya, perdagangan valuta asing dapat dianalogikan dan dikatagorikan dengan pertukaran antara emas dengan perak atau dikenal dalam terminologi fiqih dengan istilah (sharf) yang disepakati para ulama tentang keabsahannya.Hal ini sebagaimana dijelaskan dalam sebuah hadits Rasululloh.Rasulullah SAW bersabda:

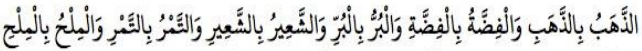

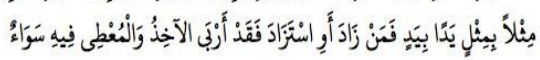
Artinya: Jika emas dijual dengan emas, perak dijual dengan perak, gandum dijual dengan gandum, sya'ir (salah satu jenis gandum) dijual dengan sya'ir, kurma dijual dengan kurma, dan garam dijual dengan

${ }^{19}$ Kusumarsono Hendarto, Belajar Trading Pahami Trading Sebelum Anda Memulai, (Yogyakarta: CV. Andi Offset, 2009), hal. 38. 
garam, maka jumlah (takaran atau timbangan) harus sama dan dibayar kontan (tunai). Barangsiapa menambah atau meminta tambahan, maka ia telah berbuat riba. Orang yang mengambil tambahan tersebut dan orang yang memberinya samasama berada dalam dosa. (HR. Muslim No. 1584)

Kegiatan transaksi forex online trading/valuta asing nya dikatagorikan dengan akad al-sharf dimana ada ketentuan karena uang merupakan salah satu komoditi riba fadbl, bahwa semua jenis mata uang di setiap negara adalah jenis mata uang tersendiri, maka kaidah-kaidah yang membawahi penukaran mata uang tersebut yang satu dengan yang lain Jika ditukar dengan yang sama maka syaratnya; Harus sama nilainya, harus diserah termakan secara langsung, jika satu jenis mata uang ditukar dengan jenis lain maka syaratnya harus diserahterimakan secara langsung.

Namun dalam praktiknya transaksi forex trading dilakukan dengan cara tidak tunai yaitu dilakukan melalui platform internet dan pembayarannya melalui rekening tujuan transaksi forex online tersebut justru untuk spekulasi dengan memanfaatkan dari pergerakan pasar, hal ini jelas tidak sesui dengan akad al sharf. Sistem Forex online trading adalah perdagangan currency atau valuta asing dengan valuta asing lainnya yang tidak melibatkan fisik dari perdagangan tersebut, melainkan hanya nilainya saja dalam satu platform internet dan tergolong dalam future market artinya tempat/fasilitas memperjual belikan instrumen keuangan dengan harga tertentu yang penyerahan barangnya disepakati akan dilakukan pada saat yang akan datang ${ }^{20}$.

${ }^{20}$ Herman Darmawi, Pasar Finansial dan Lembaga-lembaga Finansial, (Jakarta: PT Bumi Aksara, 2006), hal. 126.

\section{Kesimpulan}

Berdasarkan uraian serta penjelasan di atas, dapat diambil kesimpulan sebagai berikut : Bisnis forex adalah kegiatan mengelola modal sendiri dengan cara melakukan transaksi jual beli mata uang di pasar forex secara online untuk dapat keuntungan/profit. Setiap mata uang yang diperdagangkan ada harganya, ada pula grafik pergerakan harganya, yang dilakukan adalah jual beli barang tersebut.Sistem forex online trading adalah perdagangan currency atau valuta asing dengan valuta asing lainnya yang tidak melibatkan fisik dari perdagangan tersebut, melainkan hanya nilainya saja dalam satu platform internet (Metatrader) dan tergolong dalam future market.

Hukum transaksi forex online trading adalah haram karena tidak terpenuhinya rukun dan syarat jual beli dan mengandung unsur gharar, maisir (judi), riba dan melanggar ketentuan al-sharf yaitu adanya unsur spekulasi/untung-untungan, dan investasi ini tergolong dalam perdagangan berjangka (future market) artinya tempat/fasilitas memperjual belikan kontrak atas sejumlah komoditi atau instrumen keuangan dengan harga tertentu yang penyerahan barangnya disepakati akan dilakukan pada saat yang akan datang.

\section{Daftar Pustaka}

Abdillah, Kudrat, Maylissabet, M. Taufiq, Kontribusi Bahtsul Masail Pesantren di Madura dalam Menghadapi Perkembangan Hukum Islam Kontemporer, Jurnal Perada: Jurnal Studi Islam Kawasan Melayu, 2019. al-Jaza'iri, Syaikh Abu bakar Jabir. terj. Musthofa 'Aini, Amir Hamzah Fachrudin, dkk. 2016. Minhajul Muslim. Jakarta: Darul Haq. Anshori, Abdul Ghofur, 2009. Perbankan Syariah di Indonesia. Yogyakarta: Gadjah Mada Universiti Press. 
Bernhard Yawan, Jefri, Rudy Jozef Victor, 2010. Cara Mudah Bermain Forex Trading Online.Yogyakarta: Stih Manokwari.

Budi, Triton, Prawira, 2008. Revolusi investasi di Era Cyber dengan Forex OnLine Trading, Yogyakarta: Cemerlang Publishing.

Hayat, Abdul, 2016. Ushul Figh Dasar-dasar untuk memahami Figh Islam.Jakarta: Rajawali Pers.

Herman Darmawi, pasar Finansial dan Lembaga-lembaga Finansial. Jakarta: PT Bumi Aksara, 2006.

http://bappebti.go.id/pialang_berjangkah ttp://www.bis.org

http://brokerforex.com/legalitas-pialangluar-negeri

http://brokerforex.com/legalitas-tradingforex-dan-pialang-di-indonesia

Loen, Boy, Sonny Ericson, dkk.Manajemen aktiva pasiva Bank Devisa. Jakarta: Grasindo, 2008.

M. Sitanggang, Lucius, Yulika Indrawati, 2007. Forex Trading Real Income Psycho on Trading, Yogyakarta: Andi.

Pilliangsani, Hiqmad Muharman, 2010. Cara Mudah Memulai Bisnis Forex di Internet dengan US\$ 1. Jakarta: PT Elex Media Komputindo.

T. Suharto, Frento, 2012. Mengungkap Rabasia Forex. Jakarta: Kompas Gramedia.

Taufiq, M, Optimalisasi Peran Dewan Pengawas Syariah di Lembaga Keuangan Mikro Syariah, Al Huquq : Journal of Indonesian Islamic Economic Law, 2020.

Taufiq, M., dan Muklisin Purnomo, Model Pemberdayaan Aset Wakaf Masjid Secara Produktif Di Masjid Jogokariyan Yogyakarta, Jurnal Perada: Jurnal Studi Islam Kawasan Melayu, 2018.

Turrokman, Gisar Ari, 2019. Panduan Trading Lengkapa dari A sampai $Z$. Gisar Ari Turrokman.

Viswandro, 2014. Kamus Istilah Hukum, Yogyakarta: Medpres Digital.
Wardi Muslich, Ahmad, 2013. Fiqh Muamalat, Jakarta: Amzah.

Widoatmodji, Sawidja, Lie Ricky Ferlianto, dkk, 2012.Forex Online Trading tren Investasi Masa Kini. Jakarta: Kompas Gramedia.

Yawan, Jefry Bernhard, Rudy Jozef Victor, 2010. Cara Mudah Bermain Forex Trading Online, Manokwari: STIH Manokwari. 